\title{
Improvement of Learning Outcomes in Theme 3 Of Healthy Food Through Audio- Visual Assisted Discovery Learning in Elemenatry Schools
}

\author{
Marwanto \\ SDN Gandrungmangu 01 \\ marwanto428@gmail.com
}

\author{
Article History \\ accepted 14/11/2020
}

approved 21/11/2020

\begin{abstract}
This article describes the improvement of student learning outcomes in the thematic learning of healthy food for the content of science subjects with the discovery learning method through audio-visual. This research is a classroom action research (CAR) which was conducted in 2 cycles, each cycle consisting of planning, implementation, and reflection stages. The subjects of this study were 28 students of class V SDNGandrungmangu 01 Cilacap in the academic year 2020/2021. Data collection techniques using tests. Data analysis includes data reduction, data presentation, and drawing conclusions. Discovery learning can improve student learning outcomes in thematic learning Healthy food for science subject content for class V SDN Gandrungmangu 01 academic year 2020/2021 as evidenced by a percentage of 65\% completeness of learning outcomes in the cycle I, $75 \%$ in cycle II.
\end{abstract}

Keywords: Thematic, Discovery learning, Audio-Visual

\begin{abstract}
Abstrak
Artikel ini menjelaskan tentang peningkatan hasil belajar siswa pada pembelajaran tematik makanan sehat untuk muatan mata pelajaran IPA dengan metode discovery learning berbantuan audio visual.Penelitian ini merupakan penelitian tindakan kelas ( PTK) yang dilaksanakan dalam 2 siklus,setiap siklus terdiri dari tahap perencanaan , pelaksanaan, dan refleksi.Subjek penelitian ini adalah siswa kelas V SDNGandrungmangu 01 Cilacap tahun pelajaran 2020/2021 yang berjumlah 28 siswa. Teknik pengumpulan data menggunakan tes. Analisis data meliputi reduksi data, penyajian data, dan penarikan kesimpulan .Discovery learning dapat meningkatkan hasil belajar siswa pada pembelajaran tematik Makanan sehat untuk muatan pelajaran IPA kelas $\mathrm{V}$ SDN Gandrungmangu 01 tahun pelajaran 2020/2021 yang dibuktikan dengan persentase $65 \%$ ketuntasan hasil belajar pada siklus I, $75 \%$ pada siklus II
\end{abstract}

Kata kunci: Tematik, Discovery learning, Audio -Visual

Social, Humanities, and Education Studies (SHEs): Conference Series

p-ISSN 2620-9284

https://jurnal.uns.ac.id/shes

e-ISSN 2620-9292

This work is licensed under a Creative Commons AttributionShareAlike 4.0 International License. 


\section{PENDAHULUAN}

Permendiknas RI No.41 tahun 2007 tentang Standar Proses Pendidikan menyatakan bahwa proses pembelajaran pada setiap satuan pendidikan dasar dan menengah harus interaktif, inspiratif, menyenangkan, menantang, dan memotivasi siswa untuk berpartisipasi aktif, serta memberikan ruang yang cukup bagi prakarsa, kreativitas, dan kemandirian sesuai dengan bakat, minat, dan perkembangan fisik serta psikologis siswa dan perencanaan proses pembelajaran.

IPA merupakan mata pelajaran yang mempelajari peristiwa-peristiwa yang terjadi di alam. Pelajaran IPA di SD memuat materi tentang pengetahuanpengetahuan alam yang dekat dengan kehidupan siswa SD. Siswa diharapkan dapat mengenal dan mengetahui pengetahuan-pengetahuan alam tersebut dalam kehidupan sehari-harinya.

IPA adalah pelajaran yang penting karena ilmunya dapat diterapkan secara langsung dalam masyarakat. Menurut Srini M. Iskandar (1997: 16) beberapa alasan pentingnya mata pelajaran IPA yaitu, IPA berguna bagi kehidupan atau pekerjaan anak dikemudian hari, bagian kebudayaan bangsa, melatih anak berpikir kritis, dan mempunyai nilai-nilai pendidikan yaitu mempunyai potensi dapat membentuk pribadi anak secara keseluruhan.

Kemendikbud (2013:193) pembelajaran tematik dilaksanakan dengan menggunakan prinsip pembelajaran terpadu. Pembelajaran terpadu menggunakan tema sebagai pemersatu kegiatan pembelajaran yang memadukan beberapa mata pelajaran sekaligus dalam satu kali tatap muka, untuk memberikan pengalaman yang bermakna bagi siswa. Karena siswa dalam memahami sebuah konsep yang mereka pelajari selalu melalui pengalaman langsung dan menghubungkannya dengan konsep lain yang telah dikuasainya. Menurut Rusman (2012), pembelajaran tematik adalah model pembelajaran terpadu (integrated instruction) yang merupakan suatu sistem pembelajaran yang memungkinkan siswa baik secara individual maupun kelompok aktif menggali dan menemukan konsep serta prinsip- prinsip keilmuan secara holistik, bermakna dan otentik.

Berdasarkan beberapa pendapat di atas, penulis menyimpulkan bahwa pembelajaran tematik yaitu pembelajaran terpadu yang mengaitkan beberapa materi dari beberapa mata pelajaran dalam satu topik/ tema sehingga dapat memberikan pengalaman belajar yang bermakna.

Penelitian Tindakan Kelas disingkat PTK atau Classroom Action Research adalah bentuk penelitian yang terjadi di dalam kelas berupa tindakan tertentu yang dilakukan untuk memperbaiki proses belajar mengajar guna meningkatkan hasil belajar yang lebih baik dari sebelumnya.Penelitian tindakan kelas dapat dipakai sebagai implementasi berbagai program yang ada di sekolah, dengan mengkaji berbagai indikator keberhasilan proses dan hasil pembelajaran yang terjadi pada siswa atau keberhasilan proses dan hasil implementasi berbagai program sekolah.Tujuan penelitian tindakan kelas adalah untuk mengubah perilaku mengajar guru, perilaku peserta didik di kelas, peningkatan atau perbaikan praktik pembelajaran, dan atau mengubah kerangka kerja melaksanakan pembelajaran kelas yang diajar oleh guru tersebut sehingga terjadi peningkatan layanan profesional guru dalam menangani proses pembelajaran.Berikut definisi dan pengertian penelitian tindakan kelas dari beberapa sumber buku:

Menurut Arikunto, dkk (2006), penelitian tindakan kelas merupakan suatu pencermatan terhadap kegiatan belajar berupa sebuah tindakan, yang sengaja 
dimunculkan dan terjadi dalam sebuah kelas secara bersama. Menurut Supardi (2006), penelitian tindakan kelas adalah penelitian yang mampu menawarkan cara dan prosedur baru untuk memperbaiki dan meningkatkan profesionalisme pendidik dalam proses belajar mengajar di kelas dengan melihat kondisi siswa.

Hasil belajar merupakan bagian terpenting dalam pembelajaran. Nana Sudjana (2009: 3) mendefinisikan hasil belajar siswa pada hakikatnya adalah perubahan tingkah laku sebagai hasil belajar dalam pengertian yang lebih luas mencakup bidang kognitif, afektif, dan psikomotorik. Dimyati dan Mudjiono (2006: 3-4) juga menyebutkan hasil belajar merupakan hasil dari suatu interaksi tindak belajar dan tindak mengajar. Dari sisi guru, tindak mengajar diakhiri dengan proses evaluasi hasil belajar. Dari sisi siswa, hasil belajar merupakan berakhirnya pengajaran dari puncak proses belajar.

Discovery Learning (Pembelajaran Penemuan) adalah metode mengajar yang mengatur pengajaran sedemikian rupa sehingga anak memperoleh pengetahuan yang sebelumnya belum diketahuinya itu tidak melalui pemberitahuan, sebagian atau seluruhnya ditemukan sendiri. Sulipan (2011) menjelaskan bahwa dalam pembelajaran discovery (penemuan) kegiatan atau pembelajaran yang dirancang sedemikian rupa sehingga siswa dapat menemukan konsep-konsep dan prinsip- prinsip melalui proses mentalnya sendiri. Dalam menemukan konsep, siswa melakukan pengamatan, menggolongkan, membuat dugaan, menjelaskan, menarik kesimpulan dan sebagainya untuk menemukan beberapa konsep atau prinsip

Berdasarkan informasi yang diperoleh dan hasil observasi ,wawancara serta data hasil ulangan siswa tentang "Tema 3 Makanan Sehat muatan IPA " diperoleh keterangan bahwa jumlah 28 orang siswa kelas $V$ SDN Gandrungmangu $01 \mathrm{Kab}$.Cilacap tingkat penguasaan siswa hanya mencapai 43 $\%$.Bertitik tolak dan permasalahan tersebut, penulis bersama - sama teman sejawat melakukan identifikasi masalah sehingga terungkap beberapa masalah yang muncul dalam pembelajaran tema 3 kelas 5 sebagai berikut :

1. Kurangnya perhatian siswa terhadap pelajaran

2. Rendahnya tingkat penguasaan siswa terhadap materi pembelajaran yang diberikan

3. Proses pembelajaran kurang efektif,karena belum terjadi interaksi belajar mengajar yang optimal

4. Peserta didik cenderung pasif

5. Peserta didik kurang memberi respon terhadap pernyataan yang diajukan guru

6. Motivasi belajar siswa kurang

7. Metode dan teknik mengajar tidak variatif,sehingga timbul kejemuan bagi siswa

8. Siswa dalam belajar kurang bergairah sehingga timbul kebosanan dalam menerima pelajaran dari guru

Masalah - masalah tersebut akan ditindaklanjuti dengan mencarikan solusi pemecahanya.Berdasarkan hasil pembelajaran berlangsung, penulis merumuskan masalah yang timbul serta berdiskusi dengan teman sejawat untuk mencari penyebab dan masalah yang teridentifikasi di atas.Penyebab kurang berhasilnya pembelajaran Tema 3 muatan IPA di kelas V SDN Gandrungmangu 01 Cilacap sebagai berikut :

1) Siswa kurang menguasai pengetahuan Organ - organ pencernaan hewan ruminansia

2) Tingkat keberanian siswa untuk menjawab atau bertanya sangat kurang

3) Guru kurang menguasai metode mengajar yang variasi 
Berdasarkan identifikasi masalah tersebut di atas, maka secara spesifik masalah tersebut dapat dirumuskan sebagai berikut :

" Apakah dengan Penerapan Model Pembelajaran Discovey based Learning Berbantuan Audio Visual dapat meningkatkan Hasil Belajar muatan IPA pada Tema 3 Siswa kelas V, SDN Gandrungmangu 01 Cilacap pada Tahun Pelajaran 2020 - 2021 ?"

Bagaimana Penerapan Model Pembelajaran Discovey based Learning Berbantuan Audio Visual yang efektif untuk meningkatkan hasil belajar muatan IPA pada Tema 3 Siswa kelas V , SDN Gandrungmangu 01 Cilacap pada Tahun Pelajaran 2020 - 2021 ?"

Secara umum dengan Penerapan Model Pembelajaran Discovey based Learning Berbantuan Audio Visual diharapkan dapat meningkatkan hasil belajar muatan IPA pada Tema 3 Siswa kelas V, SDN Gandrungmangu 01 Cilacap.

Melalui Penerapan Penerapan Model Pembelajaran Discovey based Learning Berbantuan Audio Visual dapat meningkatkan Hasil belajar muatan IPA pada Tema 3 Makanan Sehat kelas V SDN Gandrungmangu 01 Cilacap

\section{METODE}

Penelitian ini menggunakan penelitian tindakan kelas yang merupakan tindakan reflektif oleh aktor untuk meningkatkan proses pembelajaran. Penelitian Tindakan Kelas adalah refleksi dari kegiatan belajar dalam bentuk tindakan, yang sengaja diangkat dan terjadi di kelas secara bersamaan. Tindakan diberikan oleh guru atau oleh arahan guru yang dibuat oleh peserta didik (Fuad and Hamam 2012; Fuad and Winarsih 2018). PTK dapat dikatakan berhasil jika peserta didik telah belajar banyak bukan berapa banyak guru bertindak. Model riset ini mencakup empat tahap tindakan yaitu perencanaan, tindakan, observasi dan refleksi. (A. Jauhar Fuad \& Ananda Dwi Permatasari, 2019 : 66).

Penelitian ini dilakukan 2 siklus. Siklus pertama dilaksanakan pada tanggal 22 Oktober 2020 dan siklus ke 2 dilaksanakan pada tanggal 2 November 2020. Subjek dari penelitian ini adalah Peserta didik Kelas V SD Negeri Gandrungmangu 01 Semester 1 Tahun Pelajaran 2020/2021 dengan jumlah peserta didik sebanyak 28.

Data kuantitatif dalam bentuk prestasi belajar kognitif, dianalisis menggunakan teknik analisis deskriptif dengan menentukan rerata atau rerata. Data kuantitatif akan disajikan sebagai persentase. Data kualitatif disajikan dalam kalimat yang dipisahkan oleh kategori untuk mendapatkan kesimpulan. Data kualitatif ini diperoleh dari mengolah data yang diperoleh dari instrumen pengamatan aktivitas peserta didik atau instrumen pengamatan keterampilan guru.

\section{HASIL DAN PEMBAHASAN}

Sebelum melakukan siklus, peneliti melakukan proses pembelajaran dengan menggunakan metode ceramah dan tanya jawab dengan materi pecahan terkait menyatakan pecahan dalam persen dan diakhiri dengan memberikan soal. Nilai pra siklus selanjutnya digunakan untuk pembagian kelompok. Tindakan pra siklus ini dilakukan pada tanggal 20 Agustus 2020.

Siklus I

Pada kegiatan pra siklus terlihat hasil bahwa kemampuan dalam menjumlahkan peserta didik masih kurang. Terlihat dari hasil belajar bahwa masih banyak peserta didik yang nilainya dibawah KKM. Siklus I ini dilaksanakan pada tanggal 2 November 2020. Pada siklus 1 guru menggunakan media audio visual untuk dapat meningkatkan kemampuan IPA peserta didik. Pada kegiatan inti, guru menampilkan video untuk 
menstimulus kemampuan peserta didik dalam menyelesaikan permasalahan yang berhubungan dengan penjumlahan. Pada siklus 2 diperoleh hasil sebagai berikut :

Tabel 1. Hasil Belajar Peserta didik Siklus I

\begin{tabular}{cccc}
\hline Nilai & Kategori & \multicolumn{2}{c}{ Siklus I } \\
& & Peserta didik & $\%$ \\
\hline $85-100$ & Sangat Baik & 5 & $18 \%$ \\
$75-84$ & Baik & 13 & $47 \%$ \\
$55-74$ & Cukup & 10 & $35 \%$ \\
$35-54$ & Kurang & 0 & $0 \%$ \\
$0-34$ & Sangat Kurang & 0 & $0 \%$ \\
& Jumlah & 28 & $100 \%$ \\
\hline
\end{tabular}

Dari nilai di atas ketuntasan belajar dari materi yang diajarkan dengan KKM 75 ada 18 peserta didik (65\%) yang tuntas. Sedangkan yang tidak tuntas ada 10 peserta didik (35\%). Pada siklus 1 rata rata kelas yang diperoleh adalah 71 . Dari data tersebut terdapat kenaikan dari $57 \%$ peserta didik yang tuntas pada pra siklus menjadi $65 \%$ yang tuntas pada siklus $\mathrm{I}$.

Siklus II

Pada siklus I setelah guru menggunakan media audio visual peserta didik sudah mengalami peningkatan. Hanya saja masih ada beberapa peserta didik yang asih mengalami kesulitan. Sesuai dengan hasil refleksi siklus I di atas maka diadakan perbaikan tindakan kelas siklus II pada IPA materi Makanan Sehat di kelas V SD Negeri Gandrungmangu $01 \mathrm{Kec}$. Gandrungmangu Kab. Cilacap semester 1 tahun pelajaran 2020/2021 dengan menggunakan model discovery learning berbantuan audio visual yang diharapkan dapat meningkatkan kemampuan peserta didik dalam tema 3 Makanan Sehat. Pada kegiatan inti, guru menampilkan media powepoint dengan gambar gambar yang menarik tentang materi materi yang akan diajarkan. Dalam powerpointpun memuat video pembelajaran yang berhubungan dengan Maknana Sehat. Siklus II ini dilakukan pada tanggal 10 November 2020. Berikut adalah hasil dari siklus II

Tabel 2 Hasil Belajar Peserta didik Siklus II

\begin{tabular}{cccc}
\hline Nilai & Kategori & \multicolumn{2}{c}{ Siklus II } \\
& & $\begin{array}{c}\text { Peserta } \\
\text { didik }\end{array}$ & $\%$ \\
\hline $85-100$ & Sangat Baik & 10 & $36 \%$ \\
$75-84$ & Baik & 11 & $39 \%$ \\
$55-74$ & Cukup & 7 & $25 \%$ \\
$35-54$ & Kurang & 0 & $0 \%$ \\
$0-34$ & Sangat Kurang & 0 & $0 \%$ \\
& Jumlah & 28 & $100 \%$ \\
\hline
\end{tabular}


Dari nilai di atas ketuntasan belajar dari materi yang diajarkan dengan KKM 75 ada 21 peserta didik (75\%) yang tuntas. Sedangkan yang tidak tuntas ada 7 peserta didik (25\%). Rata rata kelas pada siklus ini adalah 75.

Penilaian hasil pada siklus II menunjukkan guru sudah dapat memberikan motivasi pada peserta didik, guru sudah dapat mengunakan media audio visual dengan baik, guru sudah dapat mengelola kelas dengan baik dan guru sudah dapat membuat setting kelas dengan baik terutama yang dapat menjadikan peserta didik menjadi aktif.

Begitu juga hasil belajar peserta didik sudah mencapai indikator dengan KKM 75 sebanyak yaitu $75 \%$ karena ketuntasan yang di dapat 21 peserta didik atau $75 \%$, begitu juga keaktifan peserta didik pada rata - rata kelas 81 itu artinya dalam siklus II tindakan sudah baik. Dari penilaian hasil pada siklus II proses pelaksanaan, maka penelitian tindakan kelas ini peneliti hentikan.

\section{SIMPULAN}

Penggunaan model discovery learning berbatuan audio visual dapat meningkatkan hasil belajar siswa pada Tema 3 Makanan Sehat kelas V C SDN Gandrungmangu 01 Cilacap, hal ini dibuktikan dari hasil belajar pada siklus I yaitu siswa yang belum tuntas sebanyak 10 siswa dari 28 siswa atau $35 \%$, sedangkan siswa yang tuntas sebanyak 18 siswa dari 28 siswa atau 65\%. Pada siklus II, Pada kondisi awal sesuai dengan latar belakang penelitian, siswa yang belum tuntas sebanyak 10 siswa dari 28 siswa atau 35\%. Pada siklus II, siswa yang belum tuntas sebanyak 7 siswa dari 28 siswa atau 25\%, sedangkan siswa yang tuntas sebanyak 21 siswa dari 28 siswa atau $75 \%$. Ini artinya hasil belajar siswa meningkat dari siklus I ke siklus II.

Implikasi serta rekomendasi, hendaknya guru mengembangkan pembelajaran menggunakan model discovery learning berbatuan audio visual pada pelajaran yang lain.

\section{DAFTAR PUSTAKA}

Aqib, Zainal, dkk. 2011. Penelitian Tindakan Kelas untuk Guru SD, SLB, dan TK. Bandung: Yrama Widya

Discavery Learning.Dikutip dari : http://lpmpjogja.diknas.go.id. Tanggal 20 oktober 2020

Dimyati, Mudjiono. 1999. Belajar dan Pembelajaran. Jakarta : Penerbit Rineka Cipta.

Soli Abimanyu.2008. Startegi Pembelajaran.Jakarta : Dirjen Dikti Depdiknas

Sudjana, Nana. 2008. Penilaian Hasil Proses Belajar Mangajar. Bandung: PT Remaja Rosdakarya.

Trihastuti Singgih.Rimy Yoko, 2008. Pembelajaran Ketrampilan Proses, Inquiry dan 